\title{
Insolvency in the Corporate Sector and Financial Crisis in Korea
}

\author{
April 2001
}

\author{
Joon-Kyung Kim* and Chung H. Lee**
}

\begin{abstract}
The paper shows that between the late 1980s and 1997, the year when Korea was engulfed in a financial crisis, its corporate-sector profitability was on a decreasing trend, albeit short-term ups and downs. The evidence presented in the paper suggests that Korea's corporate and financial sectors had been highly vulnerable to a crisis for some years before 1997 and the actual timing of the crisis was triggered by the financial crisis in Thailand in July 1997 and its contagion effect.
\end{abstract}

Key words: Asian crisis, Korean economy, corporate sector insolvency.

JEL classification: G28, L52, O53.

* Korea Development Institute and University of Hawaii at Manoa. Financial support from the University of Hawaii Center for Korean Studies is gratefully acknowledged.

**University of Hawaii at Manoa and the European Institute of Japanese Studies, Stockholm School of Economics. 


\section{INTRODUCTION}

Although Korea's financial crisis of 1997-98 was triggered by foreign currency shortages in financial institutions, there is little doubt that financial troubles in the corporate sector, particularly the chaebols (large family-owned conglomerates), were at the epicenter of the crisis (Lee, Lee and Lee 2000). A string of corporate bankruptcies occurred in early 1997, starting with the Hanbo steel company, and these bankruptcies were directly translated into an unbearable burden of non-performing loans (NPLs) and deterioration in capital adequacy in the financial sector. These developments in the corporate and financial sectors undermined international confidence in the Korean economy, resulting in massive and sudden outflows of foreign capital.

Many have argued that the weak financial structure of the corporate sector was the core source of its financial vulnerability (Kim and Ryu 1998, Nam et. al 1999, Lee and Lee 1999). Indeed, a high debt-equity ratio had been a common feature of Korea's corporate sector and had been rising for several years before the crisis. In fact, in 1995 the average debt-equity ratio of the 30 largest chaebols was already 348 percent and then increased further to 519 percent on the eve of the 1997 crisis. This was about 6 times as large as the debt-equity ratio in Taiwan. Moreover, the debtequity ratio of those chaebols that later became bankrupt and/or subject to formal insolvency procedures was at an unsustainable level at the time of the crisis. Among these chaebols, the Halla and Jinro groups had "impaired capital" and the New Core and Haitai groups had debt-equity ratios of 1,784 percent and 1,501 percent, respectively! 
A high debt-equity ratio in itself does not, however, cause a firm's bankruptcy as long as the firm is generating enough earnings to make interest payments. It is when it fails to so that it becomes vulnerable to bankruptcy. Obviously, the more leveraged a firm is the more vulnerable it will be to bankruptcy, but what determines whether the firm will actually go bankrupt or not is the flow of earnings and thus the ability of the firm to make interest payments.

We will show below that since the late 1980s profit performance of Korea's corporate sector had been on a decreasing trend, albeit short-term ups and downs. What the evidence presented here points to is that Korea's corporate and financial sectors had been becoming increasingly vulnerable to crisis for some years before 1997 and the actual timing of the crisis was triggered by the financial crisis in Thailand in July 1997 and its contagion effect.

The rest of paper is organized as follows. Section 2 ocuments the buildup of financial vulnerability in Korea's corporate sector before the crisis. Specifically, we identify the degree to which the corporate sector became exposed to solvency risk before the crisis. To this end, we estimate the profitability, leverage, and debt servicing capacity of the corporate sector over the 1986-97 period, using a comprehensive firm-level data-set obtained from the National Information and Credit Evaluation, Inc. (Korea). We also estimate the magnitude of latent NPLs held by financial institutions prior to the crisis.

In section 3 we present a detailed description of corporate profit performance at an industry-group level before the crisis and investigate the underlying factors 
behind the declining profitability. We argue that labor costs that began to rise dramatically starting in the mid-1980s were a key factor behind the loss of international competitiveness of the corporate sector, especially the labor-intensive industries. We also argue that the emergence of foreign competitors such as China reduced the international competitiveness of Korean firms, particularly those belonging to the low technology and the medium-low technology industries. Finally, section 4 oncludes the paper.

\section{FINANCIAL LANDSCAPE IN KOREA'S CORPORATE SECTOR}

To shed light on what the corporate-sector financial landscape was like in the years preceding the crisis of 1997-98 we examine the financial data of a sample of 6,116 non-financial firms that are subject to external auditing requirements. The firms, which accounted for 53 percent of total corporate borrowings in 1997, are classified into three categories-affiliates of the top 5 chaebols, affiliates of the top 6-70 chaebols, and non-chaebol independent companies. The sample period is from 1986 to 1997.

To assess the financial health of the sample firms we first use the interest payment coverage ratio (IPCR) - the ratio of operating earnings over interest expenses, where operating earnings are the earnings before interest payment and taxes plus depreciation and amortization (EBITDA). The advantage of using EBITDA is that it is not affected by the liability structure of the firm, as it excludes interest payments, financial income, and other income or expenses. The definition of IPCR 
implies that the firms with IPCR less than one are at the risk of going bankrupt at any time and pose serious credit risks to their creditors.

Figure 1 shows the time profile of IPCR for the chaebols and non-chaebol firms over the sample period. The ratio in the figure is weighted average across firms in each category. One notable feature in Figure 1 is that IPCR for all three categories was on a decreasing trend for almost a decade prior to the crisis despite short-term ups and downs. One exception is a temporary upward blip in IPCR for the top 5 chaebols in 1994-95, which was largely due to an unprecedented boom in the semiconductor market. In fact, this upward blip disappears when three semiconductor companies affiliated with chaebols (Samsung Electronics, Hyundai Electronics, and LG Semiconductor) are taken out of the sample. Another important observation to be made is that IPCR for the chaebols excluding the three semiconductor companies was lower than that for non-chaebol firms, and the top 6-70 chaebols were most vulnerable to bankruptcy.

-- <Figure 1> Interest Payment Coverage Ratio --

The declining IPCR or the weakening debt servicing capacity of Korea's corporate sector was due to both deteriorating business performance and a rising debt leverage. Specifically, since the late 1980s business performance of firms in all three categories, measured as the ratio of EBITDA over total assets, has deteriorated (except for the three semiconductor companies affiliated with the top 5 chaebols in 1994-95) (Figures 2). Business performance of the chaebols (again except for the three semiconductor companies) was generally worse than that of the independent 
companies.

The debt leverage measured as the ratio of total borrowings to total assets rose for all firms and the ratio for the chaebols was systemically higher than that for nonchaebol firms over the entire sample period (Figure 3).

-- <Figure 2> EBITDA/Total Assets --

-- <Figure 3> Total Borrowings to Total Assets --

Table 1 provides more detailed information on the financial difficulty that Korea's corporate sector was having before the crisis by dividing firms into two groups: those with IPCR greater than or equal to one and those with IPCR less than one. As the firms with IPCR of less than one are vulnerable to bankruptcy and are not likely to pay back the loans, we regard their borrowings as latent NPLs.

\section{-- <Table 1> Latent NPLs in 1994-97 --}

It can be seen that well before the crisis of 1997-98 there were already clear signs of financial trouble in both corporate and financial sectors. In 1994, the amount of borrowings by firms with IPCR of less than one was 29 trillion won, accounting for 19 percent of total borrowings by all the sample firms. Also, the number of such firms exceeded 1,000 or 20 percent of the total in the sample. In 1995, the amount of latent NPLs increased to 32 trillion won even though the economy was in a boom. ${ }^{1}$ In 1997 ,

\footnotetext{
${ }^{1}$ According to the official data, the NPL ratio (the ratio of the sum of estimated losses, doubtful, and
} 
the year of the crisis, latent NPLs jumped to 85 trillion -2.9 times as large as in 1994. The situation was particularly serious for the top 6-70 chaebols. Interestingly, throughout the 1990s this financial vulnerability in both corporate and financial sectors did not show up at the macro level, as Korea was then experiencing rapid output growth fueled by large investment. It is clear in hindsight that in the years preceding the crisis there existed a substantial "false demand" for credits, as happened in Chile before its crisis in the early 1980s (Harberger 1985), and financial institutions simply rolled over what were essentially bad loans that had fueled an investment boom.

\section{WHY THE DECLINING PROFITABILITY IN KOREA'S CORPORATE SECTOR?}

So, what accounts for the declining profitability in Korea's corporate sector? We might argue that the chaebols' poor performance in terms of profitability vis-à-vis independent firms was due to their poor corporate governance. But, as the evidence presented above demonstrates, it was Korea's entire corporate sector that suffered declining profitability from the late 1980s on, not just the chaebols.

We argue that the declining profitability of Korea's corporate sector was a symptom of its weak and deteriorating competitive position in the world markets.

substandard loans to total loans) was low but had been decreasing until 1996 (5.8 percent in 1994, 5.2 percent in 1995, 4.1 percent in 1996). Hence, if the official data were to be believed there would not have been a substantial deterioration in bank balance sheets prior to the crisis (Hahm and Mishkin 1999) 
More specifically, we argue that rising labor costs combined with the emergence of low-cost exporters such as China have weakened Korea's international competitiveness in labor-intensive or low technology industries. Korea, however, has not been able to compensate this loss in international competitiveness with a sufficiently rapid gain in competitiveness in more technology-intensive sectors due to its weakness in innovating and adopting advanced technologies. In other words, while suffering a decline in profitability in labor-intensive, low technology industries, Korea's corporate sector has not been able to realize robust or increasing profitability in more-technology-intensive industries.

To demonstrate this point we classify the sample firms into four groups, measuring profit performance for each group separately. The four groups are low technology, medium-low technology, medium-high technology, and high technology industries based on the OECD International Standard Industrial Classification (ISIC). ${ }^{2}$

Figure 4 shows the trend in profitability, measured as the ratio of EBITDA to total assets, for each industry group for the 1985-1997 period. Both low technology and medium-low technology industries experienced a decreasing trend in profitability, their profitability rate dopping from around 10 percent in 1987 to 5-6 percent in 1997. In the medium-high technology industries there were also signs of deterioration

\footnotetext{
${ }^{2}$ Low-technology industries are food and beverage, textile, apparel, leather, footwear, chemical textile, timber, wood products, paper products, and printing. Medium-low technology industries are petroleum refineries and coal products, rubber products, plastic products, non-metallic mineral products, iron and steel, non-ferrous metals, metal products, shipbuilding and repairing, and furniture and other manufacturing. Medium-high technology industries are industrial chemicals, other chemicals, nonelectric machinery, electrical machinery, railroad equipment, motor vehicles, other transport equipment, medical and precision equipment, photographic and optical instrument, and watch. High-technology industries are office and computing equipment, electronics, communication and broadcasting equipment, and broadcast receiver/video and sound recording equipment, and aircraft.
} 
in profitability but to a lesser degree in comparison with low and medium-low technology industries. In contrast, the profit performance of the high-technology industries, which shot up markedly in 1994-95 but fell sharply in 1996-97, was considerably stronger than that of other three industry groups.

Figure 5 shows the trend in the share of troubled firms with IPCR of less than one (i.e., those firms with interest expenses exceeding operating profits). It is clear that starting in the late 1980s the proportion of such troubled firms particularly in the low and medium-low technology industries increased rapidly despite short-term ups and downs. By 1996, over 34 percent and 27 percent of the firms in the low and medium-low technology industries, respectively, were in a vulnerable position. In contrast, IPCR in the medium-high and high technology industries remained relatively stable when compared with that in the low and medium-low technology industries.

The second panel in Figure 5 indicates the amount of borrowings by firms with IPCR less than one as a share of total borrowings in each industry group. It shows a sharp increase in this share since the late 1980s with the exception of the hightechnology industries. In the latter group the share remained stable and was the lowest among the four.

-- <Figure 4> EBITDA/Total Assets by Industry Group --

-- <Figure 5> Share of Troubled Firms by Industry Group --

The sharp decline in corporate profitability in 1996-97 may be attributed to adverse cyclical factors, but structural or competitiveness problems across industries 
may underlie the slowdown since the late 1980s. One explanation, perhaps the most important one, for the competitiveness problem facing the Korean manufacturing sector during the period was the labor costs rising in excess of productivity advances with a consequent increase in the unit labor cost (ULC). Although ULC cannot be calculated for individual industries owing to the lack of data on value added, the trend of ULC in the light manufacturing and heavy and chemical industries that we report here provides some crude evidence of the deteriorating industrial competitiveness and profit performance (Table 2).

-- <Table 2> Trend of Wage, Productivity and ULC in the Korean Manufacturing --

Between 1986 and 1996, labor productivity in the manufacturing sector measured as value added per worker increased at an annual rate of 7.3 percent while wages went up by 15.1 percent per year. As a consequence, ULC increased by 7.5 percent per year. What is noteworthy is that between 1986 and 1996 labor productivity in heavy and chemical industries increased by 10.2 percent per year while that in light manufacturing increased by 5.4 percent per year. In contrast, the rate of wage increase was quite similar for the two sectors at around 15 percent. As a result, the increase in ULC in light manufacturing was twice as high (8.9 percent) as in heavy and chemical industries (4.5 percent). This explains in part why light manufacturing industries, which are all labor-intensive, suffered a marked decline in profitability since the late 1980s.

If Korean firms in light manufacturing industries had passed on the high labor costs as higher prices in the world markets their profitability would not have suffered. 
As price-takers in the global markets, however, these firms would not have been able to do so. What made the situation worse for the Korean firms was China's rapid entry into the world markets where their exports directly competed with those from China. Indeed, in the early 1980s China started to gain a comparative advantage in laborintensive manufactured goods and achieved a rapid export expansion in those products (Abe and Lee 2001, Zhang 2001).

The weakening of Korea's international competitiveness in low technology industries when China was gaining international competitiveness in the same industries can be seen in the fall of Korea's export share in two of its major export markets - the United States and Japan. As can be seen in Figure 6, China increased its export share in the United States from 1.2 percent in 1985 to 7.3 percent in 1997 , while Korea lost its share from 4.6 percent in 1988 to 2.6 percent in 1997 . Figure 7 shows that China also rapidly entered the Japanese markets with its export share rising from 5.1 percent in 1985 to 12.4 percent in 1997 while Korea's share declined from 6.3 percent in 1988 to 4.3 percent in 1997.

Despite the rapid fall of Korea's export share in the United States and Japan, Korea was able to increase its export share in the total world markets for almost a decade prior to the crisis by expanding its exports in the developing countries (Figures 8 and 9). But the fact that the Korean manufacturing sector suffered a secular decline in profitability during that period suggests that the gain in the world market share is due to the slashing of prices at the expense of profit margins and not due to improved productivity. 
-- <Figure 6> Export Share in the United States --

-- <Figure 7> Export Share in Japan --

-- <Figure 8> Export Share in World Markets --

--<Figure 9> Korea’s Export Destination-

\section{CONCLUDING REMARKS}

There are a number of reasons for Korea's financial crisis of 1997-98 such as its weak financial system and moral hazard introduced by years of government intervention in credit allocation. In this paper we have argued that there were structural causes, both internal and external, for the crisis. Starting in the late 1980s the Korean corporate sector suffered declining profitability due to rising labor costs and increasing competition in the world markets for labor-intensive, low technology manufactured products. In other words, for both internal and external reasons Korea was losing its comparative advantage in those industries.

Korea, however, has not been able to gain a comparative advantage in more technology-intensive industries rapidly enough to offset this loss, thus resulting in declining profitability generally throughout the entire manufacturing sector. In other words, Korea has not yet made the full transition from an economy specializing by and large in labor-intensive, low technology industries to an economy able to compete 
globally in industries with more advanced technologies. The crisis of 1997-98 is a symptom of the failure to make that transition when the country was faced with rapidly rising labor costs and growing competition from labor-abundant economies such as China.

\section{REFERENCES}

Abe, Shigeyuki and Lee, Chung H., 2001, "Economic Development in China and Its Implications for Japan” in M. Blomström, B. Gangnes and S. La Croix (eds.), Japan's New Economy: Continuity and Change in the Twenty-First Century, Oxford University Press.

Hahm, Joon-Ho. and Mishkin, F., 1999, "Causes of the Financial Crisis: Lessons for Policy," Korea Development Institute, mimeo, 1999.

Harberger, A., 1985, "Observations on the Chilean Economy, 1973-1983," Economic Development and Cultural Change, April.

Kim, Joon-Kyung and Ryu Deockhyun, 1998, "Debt and Financial Instability in Korea," KDI Working Paper No. 9808.

Lee, Chung H., Lee, Keun, and Lee, Kangkook, 2000, "Chaebol, Financial Liberalization, and Economic Crisis: Transformation of Quasi-Internal Organization in Korea," mimeo, Department of Economics, University of Hawaii at Manoa.

Lee, Jong-Wha and Lee, Young Soo, 1999, “The Determination of Corporate Debt in Korea," mimeo.

Nam, Il-Chong, Kim, Joon-Kyung, Kang Yeongjae, Joh Sung Wook, and Kim, Jun-Il, 1999, “Corporate Governance in Korea,” KDI Working Paper No. 9915. 
Zhang, Xiao-guang, 2000, China's Trade Patterns and International Comparative Advantage, St. Martin's Press, Inc. 